\title{
"Słowa są jak bezrobotni". Kilka wstępnych uwag na temat ekonomicznych paradoksów języka awangardy
}

"The words are like unemployed people". A few preliminary notes on the economic paradoxes of the avant-garde's language

\begin{abstract}
The paper is an attempt to outline a few problems connected with economic modes of reading the historic avant-garde, mainly its poetry. The author recapitulates a short history of its studies based on symbolic economies in order to consider possible semantic differences, resulting in the various uses of economic analogy in the discourse of the first avant-garde. The article focuses on Futurist and Constructivists movements, trying to sketch conflicts between political commitment and artistic autonomy, possible economies of sign and some sources of the "economic imagination".
\end{abstract}


* Instytut Filologii Polskiej Uniwersytetu Wrocławskiego, plac Nankiera 15, 50-996 Wrocław

e-mail: jakub.skurtys@uwr.edu.pl 


\section{Ekonomie literatury i historyczne awangardy}

Zacznę od pewnej anegdoty. Kilka lat temu, podczas konferencji Intrygi i zwroty akcji (2014), poświęconej najnowszej polskiej poezji, jeden z referatów młodszych uczestników wywołał w gronie profesorów niemałe poruszenie. W świetle teorii włoskich postoperaistów omawiana w nim była kwestia subsumcji języka pod kapitał oraz działanie analogii ekonomicznej w wierszach najmłodszych poetów. Był to mniej więcej czas, gdy ukazał się Jezzyk korzyści Kiry Pietrek, a program „korpoezji” i „poe-konomii” rozwijał Rafał Krause. Po referacie z ust jednego z profesorów, na prawach żartu, padło ironiczne pytanie: co jest stopą zwrotu wiersza? W odpowiedzi z sali powróciła genialna w swej prostocie myśl: „stopa metryczna!”. Okazało się to na tyle retorycznie sprawne i zabawne, że problem uznano za rozwiązany.

To, co zostało wówczas skwitowane wybuchem wesołości (kontekstem były napięcia wokół The Uprising Franco Berardiego, czyli głośnego, utopijnego manifestu, pisanego w imię poezji zaangażowanej społecznie - Berardi 2012), ma jednak konkretne znaczenie w kontekście studiów nad ekonomiami symbolicznymi. Otóż - o czym przeczytać możemy choćby u Anatola Sterna - grecka stopa metryczna tworzona była w relacji do rytmu kroków oraz końskich kopyt. Metrum nowoczesnego wiersza powinno się więc oprzeć - przynajmniej zdaniem naszych historycznych awangardystów - na podobnej analogii do współczesnego środka lokomocji. Pisze wszak Stern: „Moją ambicją jest sprostać galopowi oranżowego konia: elektryczności" (Stern 1972: 69).

Wraz z analogią do transportu pojawiają się w poezji dwudziestowiecznej fetyszyzowane kategorie ekonomiczne, takie jak źródła energii (ropa, węgiel i elektryczność) oraz ich relacja do czasu i ruchu. Wiersz futurystyczny miał być energetyczny jak prąa. Twórcy chcieli, żeby jego rytm oddawał spontaniczny przepływ tejże energii i gwałtowne skoki napięcia. Wiemy też oczywiście, co najmniej od Benjamina Franklina i jego eseju The Way to Wealth (pol. Droga do dobrobytu), że „time is money”, co miało konsekwencje w charakterystycznej od mniej więcej połowy XIX wieku „monetarnej reorganizacji doświadczania czasu” (Hörisch 2010: 172). Jeśli pytamy zatem, czemu poświęca się symboliczna ekonomia awangardy ${ }^{1}$ — każdej

$1 \quad$ Pojęcie „symbolicznej ekonomii awangardy” może nie być precyzyjne, dlatego spróbuję wyjaśnić je w kilku zdaniach, na które pozwala to omówienie. Po pierwsze ekonomię rozumiem w niniejszym tekście na sposób zantropologizowany, a więc nie wyłącznie jako naukę społeczną o zarządzaniu ograniczonymi zasobami, ale też jako zespół wzajemnie warunkujących się praktyk materialnych i symbolicznych (w tym również językowych 
właściwie, od futurystów i dada po sytuacjonistów i postoperaistów, od Sterna i Wata przez Witolda Wirpszę po Roberta Rybickiego i Marcina Mokrego — to możemy odpowiedzieć, że również temu: uwalnianiu języka i czasu spod władzy kapitału.

Nie tylko rytm, ujęty w metryczne stopy, ale i poszczególne figury poetyckie zyskiwały oczywiście w metaliterackiej świadomości awangardowej swoje energetyczno-ekonomiczne uzasadnienia. Gdy Adam Ważyk rozważał działanie jukstapozycji, myślał w takich właśnie kategoriach — przeskoku iskry, generowania napięcia, podobnie jak pokrewny mu ideowo Stanisław Brucz: „Znosi się niezbędne dotychczas spójniki, pozorujące łączność logiczną zdań. Każdy wiersz żyje własnym swoim życiem, posiada własny organiczny oddech, tętni wewnętrzną dynamiką swego tematu" (Brucz 1924b: 55). Gdy Ważyk wspominał w Amfionie o przerzutni jako figurze wprowadzającej chaos w czytelnicze oczekiwania, miał na myśli energetyczną eksplozję potencjału semantycznego (Ważyk 1983: 12, 49-51). Podobnie elektryczno-eksplozywne były refleksje Przybosia o jego poezji, która pozostaje przecież równocześnie poezją ucieleśnioną, chodzoną, układaną podług rytmu bijącego serca (por. Łapiński 2002).

Bruno Jasieński, domykając okres futurystyczny, wspominał, że „był to czas dziwny i piękny, czas, w którym każda strofa była pchnięciem, każdy wiersz — obroną, czas, gdzie poezje preparowało się jak dynamit, a słowo stawało się kapslą” (1972: 231). Wszak chodziło o to, abyśmy „rzygnęli przerażeniem, oparzeni gryzącymi językami żywego, eksplodującego słowa” (241). Pod tymi eksplozywno-womitywnymi metaforami ukryta jest jednak nie tylko fantazja o języku jako źródle nieskończonej energii, ale też lęk przed jej nagłym wyczerpaniem się. Nasi futuryści przerażeni byli bowiem równocześnie powojenną inflacją, opanowani ideą nadmiernego zużywania się znaków, „wycierania się” słowa poetyckiego i utraty jego wartości. Trwonili więc symboliczny kapitał na potęgę, pisali na niespłacalny nigdy kredyt, ogłaszali kolejne licytacje i „wyprzedaże starych rupieci” (Jasieński 1972: 200). Można powiedzieć, że to właśnie w opozycji do nich, do ich nierozważnej rozrzutności, Tadeusz Peiper dokonał niepowtarzalnej na skalę europejską idolatrii monetarnej, a pieniądz przedstawił jako część krwioobiegu organizmu społecznego. „Mitologia każdego czynu jest historią pieniądza. Stosunek dochodu do rozchodu decyduje o każdym przedsięwzięciu" twierdził autor Raz w poetyckiej tezie swojego najsłynniejszego tekstu programowego (Peiper 1979: 20), próbując opisać „zmianę w systemie ekonomii symbolicznej [...] na kapitalistyczny porządek symboliczny, gdzie każdą wymianą zarządzają ogólne ekwiwalenty: pieniądz w ekonomii, a znak w ramach systemu znaczącego" (Kłosiński 2015: 410).

Wszystkie te metapoetyckie ruchy dokonywały się, opierając na analogii ekonomicznej, która w latach dwudziestych na dobre zagościła w naszym życiu literackim. Jeśli spojrzeć

oraz wyobraźniowych), charakterystycznych dla danego społeczeństwa, epoki i konkretnej formacji gospodarczej. W przypadku przełomu XIX i XX wieku oraz interesującego mnie czasu świetności Wielkiej Awangardy jesteśmy wedle jednych definicji na przecięciu kapitalizmu przedsiębiorczego i menedżerskiego, wedle innych realizujemy wówczas model fordowski, a więc kapitalizm wolnokonkurencyjny przechodzi w dojrzały, fabryczny. Oczywiście echa tych przemian odbijają się w języku pisarzy, którzy pod tym samym pojęciem kapitalizmu rozumieją często inne jego fazy. Skoro ekonomia jest ujmowana dalej jako zespół praktyk i stabilizowanych przez nie dyskursów, organizujących rzeczywistość społeczno-polityczną, dość oczywiste jest jej otwarcie na wymiar symboliczny, a więc tych praktyk, które odnoszą się do ustanawiania wartości znaku w oparciu o inne, niematerialne nośniki. Samo zainteresowanie znakiem - jako podstawą dystrybucji znaczeń, a więc nadawania wartości - jest tymczasem charakterystyczne właśnie dla awangardy, która, problematyzując kwestie reprezentacji i autonomii, dokonać musiała równocześnie przemyślenia ekonomicznych podstaw relacji społecznych, w tym relacji między ekonomią polityczną i językiem. 
na powstały w podobnym czasie manifest Kurta Schwittersa Legen Sie Ihr Geld in Dada an (1919), to wprost zachęca się tam do lokowania kapitału finansowego w Dada, jako reakcję na powojenny inflacyjny kryzys w Europie. Jak zgrabnie podsumuje to Marta Baron-Milian, dokonując zręcznej ekstrapolacji:

Rzecz jasna, mamy tu do czynienia z prowokacyjną wywrotką. [...] Pokładać ufność w Dada to jak inwestować w wielki inflacyjny generator, produkujący puste, bezwartościowe znaczące. Ale w manifeście Schwittersa Dada jako wspaniała alternatywna dla wolnego rynku chytrze zmieniona zostaje w analogię. Pokładać ufność w wolnym rynku czy w jego podstawowym medium, pieniądzu, to zupełnie jak pokładać ufność w mydlanej bańce Dada. (Baron-Milian 2015: 67)

Powyższy cytat ukazuje też niezaprzeczalną zdolność literatury: figuratywne wykorzystanie języka, które przyciężkawą analogię może zmienić w krytyczną metaforę. W świetle New Economic Criticism (dalej jako NEC; por. The New Economic Criticism 2005: 17), które poważnie potraktuje metaliterackie rozważania pisarzy awangardy, relacja między stopą metryczną a stopą zwrotu wiersza nie wydaje się już najlepszym tematem do żartów, choć granice samej analogii są tu mocno rozciągnięte. Gra toczy się jednak na poważnie: o czas, o surowce (energię) oraz o ciało i percepcję, które okazują się w XX wieku instancjami coraz bardziej zależnymi od języka i podatnymi na jego ekonomiczne przemiany.

Naturalną reakcją na uświadomienie sobie przez historyczną awangardę faktu, że znak językowy i znak pieniężny działają podobnie, są różnorakie próby sproblematyzowania tej analogii, ucieczki od niej lub wykorzystania jej. Różne neo- i postawangardowe poetyki do dziś poszukują komunikacyjnej utopii wolnej od utowarowionego ruchu znaków. Pokuszę się o hipotezę, której nie jestem w stanie z oczywistych względów dowieść w krótkim szkicu: poprzez ekonomiczną metaforę, dzięki śledzeniu jej przemian w poezji, w refleksjach metaliterackich i w samej krytyce, można opowiedzieć o tym, co przydarzyło się naszej awangardzie w XX i XXI wieku, znacznie trafniej niż dzięki przyjmowanej odruchowo optyce wpływów, pokoleń i zwalczających się grup. Sporo ekonomicznych paralel między działaniem wiersza a funkcjonowaniem systemów społecznych swój początek miało właśnie na progu XX wieku, w rodzącej się wtedy antropologii, filozofii oraz teorii języka. Dlatego to właśnie literaturze awangardowej zamierzam poświęcić dalsze uwagi. Dziś te paralele wydają się jeszcze bardziej uzasadnione i właściwie przestają być wyłącznie analogiami, zmieniając się w homologie, gdy za Maurico Lazzarato czy Christianem Marazzim powtórzymy, że żyjemy w epoce semiokapitalizmu (kapitalizmu kognitywnego), a więc kapitalizmu opartego na spekulacji znakami i utowarowieniu procesów poznawczych (por. Marazzi 2008; Lazzarato 2014).

Badanie ekonomii symbolicznych przez wiele lat od wypracowania samej koncepcji nie było w polskim literaturoznawstwie obecne. Od przejścia teorii z dziedziny antropologii, opisującej wymianę i jej symboliczne implikacje (powiedzmy od Bronisława Malinowskiego do Marcela Maussa i Claude'a Levi-Straussa) oraz od dedykowanych „ekonomii reprezentacji” studiów z pierwszych numerów „Tel Quel” (Goux 1990), do pojawienia się u nas wzmianek na ten temat minęło trzydzieści lat. Postulat konieczności odniesienia się do krytyki ekonomicznej, w tym przypadku spod patronatu Marca Shella (2015), sformułował na początku stulecia Michał Paweł Markowski (2004) i po części rozwinął go w Polskiej literaturze nowoczesnej (2007: 97-10). Kilka ostatnich lat przyniosło jednak szereg prac, które nie tylko podjęły się tłumaczenia tekstów różnych szkół teoretycznych (Literackie ekonomie 2017), ale też zaproponowały własną refleksję o rodzimej literaturze (Baron-Milian 2015; Kłosiński 2015; 
Ruszar 2016; Tomczok 2018; Romantyczny antykapitalizm 2018). Można powiedzieć, że po wielkim kryzysie bankowym z lat 2008-2012 mamy zasadnicze ożywienie wspomnianej perspektywy. Większa jej część skupia się - co nie powinno dziwić - właśnie na literaturze XIX i początku XX wieku, jako kluczowej dla zrozumienia literackiej refleksji nad nowoczesnymi kryzysami w przemysłowym i kognitywnym kapitalizmie.

To wzmożone zainteresowanie ekonomiami symbolicznymi literatury nie znaczy oczywiście, że najciekawsze tematy zostały już zgłębione, a między badaczami nie ma wyraźnych różnic. Opracowanie awangardy dwudziestolecia sprowadza się nadal głównie do kilku studiów nad futurystami i Peiperem (Baron-Milian 2015; Kłosiński 2015: 396-419; 2017: 89107). Problematyka neoawangardy w całości czeka dopiero na takie omówienie. Podejście Michała Kłosińskiego jest na ogół zorientowane na wymianę symboliczną w zgodzie z filozofią Jeana Baudrillarda (dało to zaskakująco dobre efekty w rozpoznaniu ekonomii języka Schulza - Kłosiński 2015: 227-288; ale średnio sprawdza się w badaniu historycznoliterackim). Paweł Tomczok czerpie z nowszych interpretacji marksizmu oraz tradycji psychoanalityczno-strukturalnych, od których Baron-Milian starała się z kolei trzymać z daleka. Rekonstruuje ona raczej coś, co na potrzeby niniejszego tekstu nazwałbym „wyobraźnią ekonomiczną” danego autora, a więc pole wyznaczane przez świadomość ekonomiczną twórców oraz wykreowany przez nich dyskurs literacki. Do takiego myślenia jest mi najbliżej. Zgadzam się jednak ze słowami Tomczoka i Kłosińskiego ze wstępu do jednego z tomów serii „Ekonomia literatury”, iż bez „rozbudowanej teorii ekonomia literatury może być tylko bezładnym gromadzeniem anegdot ekonomicznych pojawiających się w tekstach" (Ekonomiczne teorie literatury: 7). Dlatego, nawet mimo przyjętej tu historycznoliterackiej raczej niż teoretycznej perspektywy, podstawowymi polami odniesienia pozostają dla mnie teoria systemów komunikacyjnych oraz marksizm (Tomczok proponuje myśleć za Marksem — a następnie w zgodzie z tropami Simmela i Sohn-Rethela — o toposach ekonomicznych jako „realnych abstrakcjach” i ta propozycja wydaje się inspirująca, łączy bowiem krytykę tematyczną z zaangażowaniem w konkretne, pozaliterackie wydarzenia — Tomczok 2017: 19-22]).

\section{Dwie ekonomie, czyli o paradoksie zaangażowania}

Jednym z najważniejszych dziś pytań wydaje mi się to, jak analogia ekonomiczna, rozpatrywana od strony NEC, ma się do wpisanego w rdzeń awangardowego myślenia napięcia między autonomią sztuki i postulowanym zaangażowaniem w zmianę świata. Jako badacze historycznych awangard uznaliśmy bowiem, na ogół w zgodzie z heglowską dialektyką (Poggioli 1981; Bürger 2006; Morawski 2007; por. Świeściak 2015), że misja awangardy musi się zakończyć klęską (zamilknięciem, porzuceniem postulatów, ogólnym kryzysem języka) albo przeobrażeniem świata, który wchłonie awangardę w siebie i w ten sposób zniesie ją bądź utowarowi. Spojrzenie na dyskurs awangardowy od strony ekonomii symbolicznych wystawia jednak tę dialektyczną logikę na próbę i pozwala odpowiedzieć na pytanie, dlaczego mimo porażki historycznej formacji awangardowej (a potem neoawangardowej i zapewne również postawangardowej), coś, co określilibyśmy jako wiarę w skuteczność i niezbędność awangardowego gestu, powraca nawet w społeczeństwach zaawansowanego kapitalizmu kognitywnego ${ }^{2}$.

2 Najlepszym dowodem na to niech będzie przecinający najmłodszą poezję impuls eksperymentatorski, poszukujący patronatów w poetykach dwudziestolecia międzywojennego, a wspierający się wierszami Roberta Rybickiego i historyczno-awangardowymi alegacjami Andrzeja Sosnowskiego, w tym współredagowaną przez niego wraz z Joanną Orską antologią Awangarda jest rewolucyjna albo nie ma jej wcale (2019). 
Rodzima awangarda lat dwudziestych i trzydziestych przede wszystkim musiała krytycznie ustosunkować się do estetyki materialistycznej. Powstała konieczność rozgraniczenia ekonomicznej refleksji nad literaturą, która ujmuje ją w pierwszej kolejności jako zjawisko społeczne, oparte na stosunkach klasowych (a więc narzędzie ideologicznej walki) od takiej, która ekonomiczną refleksję przeprowadza na samym języku literackim i siłą analogii przeciwstawia się materializmowi historycznemu. Dobrze ujmuje to szkic Józefa Łobodowskiego, wówczas jeszcze autora mocno lewicowego. Pomny rozczarowań w samej „Zwrotnicy”, wzywając w „Dźwigarach” pisarzy awangardowych do nieporzucania walki o zmianę społeczną i do nierezygnowania z literatury, przypomina w duchu rosyjskich formalistów, że celem awangardy nie jest ideowe uproszczenie i jednoznaczność, ale komplikowanie, unikanie solipsyzmu i dezautomatyzacja:

\footnotetext{
Napisanie wiersza rewolucyjnego nie oznacza jeszcze przełamania burżuazyjnego świata - oznacza jego negację. [...] Stwierdzam śladem „Nowego Lefu”: „ideologia nie tkwi w materiale, którym posługuje się sztuka. Ideologia tkwi w chwytach obróbki tego materiału, ideologia - to forma. Jedynie celowa formalizacja materiału wyprowadza na drogę społecznego przeznaczenia. Zmiana tematu — to drobiazg..... [...] Na pytanie „czym jest sztuka?”, nie wolno odpowiadać „sztuka jest narzędziem walki klasowej”. Natomiast faktem jest, że sztuki, której istota da się określić tylko w granicach estetycznych, klasy społeczne używają zawsze i wszędzie, jako narzędzia w walce z innymi klasami. Jeszcze trafniej — sztuka jest terenem walki klas. (Łobodowski 1934/35: 104)
}

Już tutaj możemy zasygnalizować pierwszy z interesujących paradoksów ekonomicznego dyskursu awangardy, czyli krytyczne napięcie między ekonomią symboliczną (języka i reprezentacji) a ekonomią polityczną: albo zbyt łatwe utożsamianie jednej z drugą, albo nawoływanie do porzucenia jednej na rzecz drugiej. Jako kontekst warto przywołać dobrze znaną propozycję Michała Pawła Markowskiego z Polskiej literatury nowoczesnej. Interpretacyjnie produktywna „nowoczesność krytyczna” przeciwstawiona tam zostaje niechcianej, bo nie aż tak produktywnej, „nowoczesności zachowawczej”. Pozostaje jednak Markowskiemu szereg autorów, którzy wymykają się z obu grup (lub dowolnie między nimi krążą) i muszą utworzyć grupę trzecią, dziwaczą i efemeryczną, która ma tendencje do tracenia reprezentantów, gdy tylko staną się oni dla badacza wystarczająco interesujący. Ta grupa to oczywiście awangarda (Markowski 2007: 42-45).

Problem rozprawy Markowskiego polega oczywiście na poststrukturalnym impasie, charakterystycznym dla momentu, w którym autor ją pisał, a dotyczącym kategorii referencyjności. Nowoczesność konserwatywna wierzy wbrew wszystkiemu w możliwość zachowania językowej referencji, a nowoczesność krytyczna skupia się na problematyzowaniu tej kategorii, generując w ten sposób ważne dla nas (w XXI wieku) napięcia. Markowskiego interesował jednak tylko znak i jego krążenie w zamkniętym, autopojetycznym systemie literatury (a więc jego samopotwierdzanie się lub kwestionowanie). W tak ustawionej optyce awangardzie przypada paradoksalne miejsce: reformatorki języka, która wierzy w konserwatywną referencję, eksperymentatorki, która nie jest krytyczna wobec własnych narzędzi, wreszcie potencjalnej rewolucjonistki społecznej, która doskonale wpasowuje się w zastaną postać świata.

Powyższy problem z opisem pierwszej awangardowej formacji nie powstałby, gdyby Markowski nie oparł całej typologii na zawoalowanym ataku na referencyjność. Wyznawana przez badacza teoria krążenia znaków w zamkniętych systemach zakłada poststrukturalną świadomość niedającego się znieść pęknięcia między systemem społecznym i systemem językowym. 
Ale nie jest to świadomość ahistoryczna, ostateczna i niedająca się przezwyciężyć. Wydaje się raczej charakterystyczna dla pewnego momentu ponowoczesnego przesilenia w rodzimej teorii literatury, gdy patronaty wczesnego Jacques’a Derridy i Rolanda Barthes’a powoli ustępowały innym inspiracjom. Warto więc zapytać, czy ekonomiczne analogie pierwszej awangardy, a więc analogie próbujące wykazać ścisły związek między systemem językowym i systemami gospodarczymi, nie stały w oczywistej sprzeczności z tak wąsko pojmowanym pęknięciem między światem i językiem?

Język zmienia świat — to dziś założenie oczywiste. Ale w jaki sposób go zmienia? W jaki sposób pozostaje w zgodzie z tym światem, i to w zgodzie, która jest równocześnie krytycznym konfliktem, skoro rzeczywistość wydarza się teraz, język awangardy zaś zawsze przemawia do świata przyszłego, tego, który chce dopiero powołać? W tym sensie - użyjmy jednej z bardziej wyświechtanych metafor całych studiów nad ekonomiami symbolicznymi - język awangardy jest używaniem znaków na kredyt, którego spłata nastąpić ma w nieodległej przyszłości, po rewolucji i gruntowej przemianie stosunków społecznych (możemy więc założyć, biorąc pod uwagę mechanizmy inflacyjne, znane doskonale w latach dwudziestych, że ta spłata nigdy nie nastąpi). W pisaniu na kredyt nie ma jednak miejsca na zamknięty i samozwrotny system języka, który skrywa - jak chce Markowski — jedynie pustkę, którego sednem jest pusty znak o zerowej wartości, obnażający niestabilne fundamenty całej językowej ekonomii. To oczywiście lekcja, którą badacz wynosi od Derridy, po części również od Jacques’a Lacana. Ale to nie jest lekcja awangardy, żadnej z awangard (neo-, post-), które podejmowały się raczej kwestionowania języka i jego zastanych reguł z przekonaniem o możliwości zmiany świata, bezpośredniej lub pośredniej (systemowej) interwencji. Wiara w oddziaływanie języka na rzeczywistość pozostaje u awangardystów zawsze w zgodzie z autonomią sztuki, bowiem sztuka, jako specyficzny tryb użycia tegoż języka, jest terenem walki, nie zaś samą walką. Terenem walki jest wobec tego język jako forma komunikatu i tylko jej zmiana doprowadzić może do zmiany świata, głównie poprzez wymianę systemów oznaczania i sposobów nadawania wartości ${ }^{3}$.

Jak pisze Andrzej Turowski w Wielkiej utopii awangardy: awangardę interesowała nie tyle referencyjność mimetyczna (jak widzi to w dużym uproszczeniu Markowski), ile komunikacyjna utopia przejrzystego języka, obiecanego już w innym świecie (Turowski 1990: 179-198). Konflikt między zaangażowaniem i autonomią w obrębie każdego ruchu awangardowego trzeba by więc postrzegać raczej jako dialektykę, w której ideologiczność zmaga się z obietnicą komunikacyjnej utopii. Jeśli spojrzeć na naszą pierwszą awangardę, drogi do tej utopii okażą się bardzo różne: od Peiperowskiego funkcjonalizmu (wręcz ekonomicznego tayloryzmu, skupionego na hiperproduktywności języka), do typowo futurystycznego przekonania o konieczności doprowadzenia do krachu burżuazyjnej ekonomii poprzez krach jej systemów semiotycznych (podzielanego przez Wata w latach dwudziestych, ale i przez Rybickiego dzisiaj). „Awangarda nie opisuje świata, lecz świat poddany «władaniu języka burżuazji». To jest awangardowa powierzchnia” — pisze Turowski, odnosząc się do Logiki

3 To właśnie ta część refleksji marksistowskiej pomijana była na ogół przez analizę klasową i materializm historyczny, również w naszej krytyce literackiej (Fik, Stawar, Stande). Rozpatrywanie literatury z perspektywy relacji między bazą i nadbudową cierpi na znany wszystkim marksistowskim studiom problem reprezentacjonizmu i koniec końców prowadzi raczej do socjologii literatury niż do krytyki czy poetyki. Z perspektywy literaturoznawstwa to marksowska teoria wartości wydaje się dziś zacznie bardziej przydatna do opisu przemian kapitalistycznych niż pojęcia klasy czy bazy. Kluczową rolę odgrywają tu kategorie „intelektu powszechnego” i „produkcji niematerialnej”, sproblematyzowane przede wszystkim przez włoskich postoperaistów. Por też: Graeber 2001: 23-47. 
sensu Deleuze’a (197). „Struktura dzieła awangardowego, naruszając własną zasadę kodową, prowadzi ustawiczną grę przedstawiającego z przedstawianym. Celem jest destabilizacja tego związku, prowadząca ku przezwyciężeniu własnego znakowego ograniczenia” (187-188).

Jest to propozycja refleksji nad awangardą z wnętrza wytworzonego przez nią dyskursu, ale bez zerwania opartej na analogii współzależności między systemami semiotycznymi. Co ważniejsze, o ile kwestionowanie własnej formy artystycznej jest każdej awangardzie niezbędne, o tyle przekroczenie tego wewnętrznego namysłu i eksterioryzacja go na porządki społeczne jest tym, co awangardy od siebie odróżnia. Turowski nazywa to „radykalizmem syntagmatycznym" i właśnie tak warto rozpatrywać bardziej lub mniej umiejętne wycieczki awangardzistów na tereny ekonomii politycznej poprzez ekonomie symboliczne lub jeszcze bardziej karkołomnie, z ich jawnym pominięciem. Stawką awangardowej walki o język nie jest po prostu referencyjność (a jej podłożem wiara w mimesis), ale utopia komunikacyjna, przybierająca postać niedającej się zredukować potencjalności semiotycznej. Ta utopijność awangardy, jako atrakcyjna polityczna obietnica i zobowiązanie, będzie powracać i u neoawangardzistów, i u poetów współczesnych, nawet tych najbardziej zadłużonych w poststrukturalnych teoriach języka.

\section{Ekonomie języka poetyckiego}

Jeśli zajrzymy do słownika Michała Arcta z 1916 roku, a nawet do wcześniejszego jeszcze Stownika warszawskiego, odnajdziemy tam czasownik 'ekonomizować, tj. 'oszczędzać' (od francuskiego économiseur). 'Ekonomja' to wówczas 'rządność,' 'gospodarność i 'oszczędność, dopiero zaś 'ekonomia polityczna’ określona zostaje jako nauka o bogactwie narodów (oba jednak wywiedzione są z greckiego źródłosłowu oikonomikós, a nie z popularnego dziś wśród badaczy rozdzielenia oikos + nomos). W regularnym użyciu był jeszcze na początku XX wieku wyraz 'ekonom' (a więc zarządca) i wszystkie związane z nim słowa pochodne. Z użytku wychodziły zaś określenia na dobra królewskie i wchodzący w nie spis inwentarza (również jako 'ekonomie', o czym wspomina choćby słownik Lindego). Jeśli cofniemy się do początku XIX wieku, zauważmy, że przymiotnik 'ekonomiczny' to u Lindego 'rządny' i 'gospodarny', ale też 'ścisły' i 'wstrzemięźliwy', bo pojęcie to obejmuje również przymioty moralne. Za Zabłockim podaje Linde cytat: „Przestrzegać należy, aby ekonomia nie przemieniła się w łakomstwo”, gdzie ekonomia oznacza po prostu wstrzemięźliwość moralną (Linde 1804: 615).

Jak zapowiadał Jean Cocteau, przetłumaczony w ostatnim numerze „Almanachu Nowej Sztuki” przez Wata, w ostatnim z zamieszczonych tam fragmentów Le Secrete Professionel: „Poeta nie marzy. On liczy. Lecz kroczy po piaskach ruchomych i czasem noga jego pogrąża się w śmierć" (Cocteau 1925). W oryginale czytamy: "Le poète ne rêve pas: il compte” (Cocteau 1922: 62), co możemy przełożyć jako 'oblicza', 'rachuje', 'kalkuluje'. Powszechna była u awangardystów wszystkich ugrupowań świadomość tego ekonomicznego paradoksu, konieczności ostrożnego, racjonalnego, a więc produktywnego poruszania się w nowoczesnym już polu, wyznaczonym przez relacje języka i kapitału, zderzanej z ryzykownymi próbami przekroczenia pola i zdestabilizowania go, na czele z hazardem, dziecięcymi zabawami i niewymiernym wydatkowaniem, zaprzeczającym mieszczańskiej logice (co okaże się charakterystyczne dla kultu płodności w manifestach naszych futurystów, ale też np. dla ekonomii solarnej Georges'a Bataille’a i surrealistów francuskich).

Najbardziej znanym przypadkiem XX-wiecznego przemyślenia ekonomii symbolicznej w poezji jest oczywiście twórczość Ezry Pounda (por. Rabaté 1986: 183-241; Sieburth 1987; 
Marsh 1998). Można powiedzieć, że w tej kwestii nasi pisarze przychodzą trochę na gotowe. Konieczność uwzględnienia ekonomii jako systemu refleksji o literaturze postulowali wcześniej Stanisław Brzozowski, a nieco później Karol Irzykowski, choć myśl o połączeniu estetyki z ekonomią pozostawała wciąż do przepracowania. Powracała w kręgach futurystów i formistów, krążyła przez pisma „Zwrotnicy”, odkształcała się w rozprawach Stefana Kordiana Gackiego, potem meandrowała w „Linii” i „a.r”. Czasem — jak w przypadku Peipera - zyskiwała teoretyczną podbudowę, czasem ujawniała się tylko jako wzmianki, postulaty, wezwania. Doskonałym przykładem jest tu choćby konflikt między Peiperowską ekwiwalentyzacją i metaforą a Ważykową jukstapozycyjnością i preferowaniem metonimii, pozornie przynajmniej regulującej wymianę znaczeń („coś” jako część „czegoś innego” zamiast wymiany „czegos" na „coś innego”).

Ta refleksja nad językiem nowoczesnej poezji i jego relacją ze światem doprowadzi poszczególnych twórców do zupełnie inaczej ukierunkowanych, symbolicznych ekonomii: u Peipera i jego uczniów poskutkuje iście weberowską pochwałą kapitalistycznej akumulacji, która przerodzi się wręcz w tayloryzm; u futurystów objawi się jako pokrewna Bataille’owskiej ekonomii trwonienia i zatraty, której celem będzie przeciążenie systemu znakowego, jego burżuazyjnej powierzchni. Peiperowska próba napisania nowej antropologii ewolucyjnej na bazie ekonomicznego funkcjonalizmu to rzeczywiście niemałe wyzwanie, zwłaszcza że w antropologię tę włączy autor również teorię wartości i pochodną jej estetykę. Podstawowy kierunek myślenia będzie tu jednak wyznaczała lingwistyka, i to lingwistyka jeszcze XIX-wieczna. Jak stwierdzi w „Zwrotnicy” autor Raz, broniąc przed Iwaszkiewiczem używanej przez siebie archaicznej formy „wartałoby” i powołując się na tezy niemieckich młodogramatyków: „Ekonomia mowy jest jednym z praw rozwoju języka. A ekonomizm — jednym z haseł nowej literatury" (Peiper 1923: 117). Między ewolucjonistycznymi teoriami, związanymi ze sformułowaniem prawa rozwoju języków, ekonomią środków jako zasadą budowy dzieła a koncepcją sztuki masowej i utylitarnej jest jednak tylko wiara Peipera właśnie w działanie ekonomicznej analogii.

Pewną rolę w popularyzacji tej analogii odegrały z pewnością prace socjalistów i marksistów, w tym samego Marksa. Sformułowana już w pierwszym tomie Kapitatu analogia między językiem i pieniądzem była rzeczą tak oczywistą, że trudno stwierdzić, czy należała po prostu do stałych chwytów retorycznych autora, czy też stanowiła trzon myślenia porównawczego na temat symbolicznej struktury nadbudowy (nowsze lektury skłaniają się raczej ku tej drugiej interpretacji). Pisał Marks:

Skoro obieg pieniężny sam oddziela realną zawartość monety od jej zawartości nominalnej, jej byt kruszcowy od jej bytu funkcjonalnego, kryje on w sobie możliwość zastąpienia pieniądza kruszcowego w jego funkcjach monetarnych przez znaki z innego materiału lub symbole. (Marks 1951: 132)

To oddzielenie „realnego" od „nominalnego" oraz idące za nim rozsunięcie między towarem i odpowiadającą mu wartością tworzy oczywiście pretekst do spekulacji. Jest też podstawą badań nad ekonomiami symbolicznymi (por. Goux 1990).

Drugim źródłem popularności analogii monetarno-językowej w dwudziestoleciu wydają się wczesne wykłady Ferdynanda de Saussure’a z Kursu językoznawstwa ogólnego (1916), w których aż roi się od porównań systemu językowego z systemem ekonomicznym, a wymiana okazuje się głównym mechanizmem tworzenia znaczenia (signifié i signifiant to dwie 
strony monety). Jak zauważał Ryszard Nycz w Jezyku modernizmu — początek XX wieku upływał jeszcze pod hasłami ekspresjonistycznymi, skupionymi na jednorazowości wypowiedzi, na parole. Awangarda jest już jednak formacją, która w pełni odkryła langue jako system, i to system semiotyczny, w takim samym stopniu jak inne oparty na podstawowej, opisanej przez Marksa operacji - powstawaniu wartości na skutek wymiany, cyrkulacji znaków (Nycz 1997: 45-59). Powołajmy się też na diagnozy Romana Jakobsona z opublikowanego w roku 1933 eseju Co to jest poezja?:

Druga połowa XIX wieku była okresem szybkiej inflacji językowych znaków. [...] Empiryzm i naiwny realizm w filozofii, liberalizm w polityce, kierunek młodogramatyczny w językoznawstwie, kołyszący iluzjonizm w literaturze i na scenie, czy to będzie naiwność naturalistycznej iluzji, czy solipsystyczna iluzja dekadencka, atomizujące metody literaturoznawstwa (a właściwie nauki w ogóle) — tak się nazywają rozmaite źródła, za pomocą których ratowano kredyt słowa i wzmacniano wiarę w jego realną wartość.

A teraz! Współczesna fenomenologia konsekwentnie ukazuje językową fikcję i dowcipnie uzasadnia podstawową różnicę między znakiem a oznaczonym przedmiotem, między słownym znaczeniem a treścią, do której się to znaczenie odnosi. Paralelnym zjawiskiem na polu społeczno-politycznym jest namiętna walka przeciw różnym szkodliwie abstrakcyjnym, mglistym słowom i frazom, ideokratyczny bój przeciw „słowom-oszustom”, zgodnie z obrazowym wyrażeniem. (Jakobson 1989)

Te językoznawcze wycieczki literatów stwarzają kilka przynajmniej pól do refleksji nad popularnością ekonomicznego myślenia. Po pierwsze język artystyczny wchodzi w mariaż z językiem naturalnym, spożytkowanym na potrzeby reklamy czy od początku użytkowanym w ramach systemów handlowych. Wspomniane przez Jakobsona naiwne zaczarowywanie musiało w końcu ustąpić tezie o całkowitej arbitralności, a tym samym wymienności znaków. To prowadzi do walki o oczyszczenie języka z pustosłowia i nawet w samej literaturze przekłada się na postulaty ekonomizacji wypowiedzi i ekonomizacji myślenia, dążenia do klarowności, odsłonięcia reguł całego procesu wymiany.

Dalej, jeśli wziąć pod uwagę, że analogia ekonomiczna w języku pierwszej awangardy ma w sobie tyle z rzeczywistego rozpoznawania koniunktur gospodarczych (aspekt teoretyczny) oraz sytuacji po pierwszej wojnie (aspekt socjologiczno-praktyczny), ile z etyki, dostrzeżemy, że funkcjonuje ona w pismach metaliterackich epoki na różnych poziomach. Odniesienie jej do samego wiersza, a więc pola estetycznego, a dalej językowego, jest ostatnim etapem, przy czym na ogół pomija się (tak w opracowaniach, jak i w samych tekstach programowych) fazy pośrednie i występujące między nimi przesunięcia semantyczne. 'Ekonomiczność' w dyskursie pierwszej awangardy rozumiana jest bowiem na trzy co najmniej sposoby: 1) jako postulat związany z kondensacją i nadorganizacją wypowiedzi (co prowadzi nas wprost do rosyjskich formalistów i późniejszej poetyki strukturalnej, jeśli chodzi o reguły wiersza, natomiast w kwestii praxis naturalnie łączy się z fordyzmem i tayloryzmem); 2) jako postulat klarowności tejże wypowiedzi (komunikacyjnie chodziłoby tu o stworzenie demokratycznej, racjonalnej wspólnoty rozumiejących się obywateli/mężczyzn, a więc spełnienie dialektyki oświecenia, poetycko — o oszczędność słów i emocji oraz preferowanie prostoty języka); 3) jako analogia do ekonomii politycznej, związana z pojęciem rewolucyjnej zmiany społecznej (co prowadzi nas z kolei do problemu utożsamienia ideologii z utopią, a praxis z poiesis). 
W pierwszym i drugim kontekście mamy do czynienia z refleksją nad językiem oraz mniej lub bardziej uświadomioną filozofią znaku. Innymi słowy, nic nie stoi na przeszkodzie, żeby Peiper, Kurek czy Gacki postawili obok ekonomiczności - wzorem Marinettiego - męskość kulturowo połączoną właśnie z racjonalnością i komunikatywnością. Czymś takim jest przecież zaczerpnięta od Brzozowskiego „ekonomia duszy” Gackiego - czyli, jeśli przypomnimy, że dusza funkcjonowała w latach dwudziestych wymiennie z pojęciem świadomości i psyche - ekonomia samej świadomości (Gacki 1925a: 62-63). Jak pisze z kolei Przyboś w „Zwrotnicy”: poeta „ujęty w dyscyplinę ekonomji wypracował w sobie godność męskiej lakoniczności; nie narzuca się bezwstydnie z słowami, śliniącego (sic!) łzami i plującemi wrzaskliwą radością” (Przyboś 1926: 210). Przytoczmy kilka innych przykładów: „Materiał oczyszczony. Wiązania precyzyjne, jasne. Całość zmontowana z maksymalną ekonomią" (Gacki 1925b: 7); „kompozycję doskonałą, tj. ekonomiczną i żelazną — minimum materiału przy maksimum osiągniętej dynamiki - nazywamy kompozycją futurystyczną” (Jasieński 1972: 212). Ekonomiczność to w powyższych przypadkach wydajna organizacja materiału, w zależności od kontekstu: etyczna (duchowa) lub estetyczna. Otwartość semantyczna pojęcia sprawia jednak, że łatwo o językowe potknięcie. W czwartym numerze „Linii”, w programowym szkicu, definiując nową poezję w odniesieniu do form życia zbiorowego (ale myślami będąc w autonomicznym polu sztuki), Jalu Kurek opisywał ją prostymi jeszcze pojęciami: „celowość, ekonomja, szybkość, skrót, kondensacja”. Dalej jednak sformułował dość niezręczny fragment, który dał tytuł niniejszemu wprowadzeniu:

Umiar i wybór są zasadniczymi elementami tworzenia artystycznego. Dalej: — linia prosta. Najkrótsze połączenie wizji z przedmiotem. Li r y z m telegrafic zny. Słowa są jak bezrobotni. Kiedy ich nie potrzebujemy, chcą choć otrzymać zasiłek. Nie ulegajmy im. Nie płaćmy tego haraczu na rzecz gadulstwa. (Kurek 1932: 86)

Tomczok uznałby to pewnie za typową anegdotę, ale jest ona dość symptomatyczna. Oto bowiem lewicowy twórca o nastawieniu wyraźnie socjalistycznym przez przypadek porównuje słowo poetyckie do bezrobotnych i brzmi jak typowy kapitalista XIX-wieczny, jakby pisał wezwanie do stłumienia strajku robotniczego, „zasiłek” utożsamiając z „,haraczem” ${ }^{4}$. To drobne nadużycie pokazuje wyrwę w samym sercu konstruktywistycznej analogii ekonomicznej "Zwrotnicy” i „Linii”. Pojęcia ekonomiczne, poddane wymogom funkcjonalizmu, nie zawsze przystają do kategorii estetycznych, a sama analogia bardzo łatwo ulega automatyzacji.

W trzecim znaczeniu, związanym ze zmianą społeczną, analogia ekonomiczna wprost implikuje ekonomię polityczną i stara się przedstawić relacje językowe jako wychyloną w przyszłość (utopijną) zapowiedź zmiany, w myśl założeń, że estetyka w swoim tempie przekształca społeczeństwo. To trzecie znaczenie jest zresztą różnorako rozwijane przez wszystkie okołoawangardowe grupy przez cały XX wiek. Raz będzie to dążenie do klarowności i kondensacji w myśl zasady oszczędzania energii i jej produktywnego zużycia na rzecz późniejszej zmiany społecznej (jako szczególny rodzaj filozofii pracy), innym razem dążenie do bezmiernego wydatkowania (poprzez zaburzanie sensu, szum, bezsens, zakłócenie), jako wyzwania rzuconego pragmatycznemu, burżuazyjnemu lub mieszczańskiemu podejściu. Możemy to zaobserwować w poetykach futurystycznych i dadaistycznych oraz tych współczesnych, w dużej mierze nimi inspirowanych (u Andrzeja Szpindlera, Roberta Rybickiego i Piotra Przybyły).

4 Nie powinno dziwić, że w książkowym przedruku tego eseju to niezręczne wezwanie przeciw bezrobotnym, wymuszającym haracz, zostało usunięte. 


\section{Wyobraźnia ekonomiczna}

Większość wspomnień historycznej awangardy - Ważyka, Brzękowskiego, Peipera, Jasieńskiego, Kurka, a nawet Wata - uświadamia nam jednak, jak nikła była w międzywojniu wiedza samych poetów o ekonomii. Opierała się na ogół na pewnym zdroworozsądkowym porządku pozytywistycznie pojętego produktywizmu i teoriach organicznych rodem z XIX wieku. Peiper stworzył oczywiście w swoich pismach koncepcję wyglądającą na antropologiczną, zakorzenioną w ewolucjonizmie i opartą na metaforze organicystycznej, w której połączył ekonomiczność jako kategorię estetyczną z ekonomią polityczną, ale teoria ta ma charakter powierzchowny i zaledwie udaje pogłębione studium. Jasieński swoją wiedzę ekonomiczną uzupełniać zaczął dopiero w drugiej połowie lat dwudziestych, gdy napisał już większość kluczowych dzieł z okresu futurystycznego Sturm und Drang. Wat w książki profesjonalnych ekonomistów zagłębił się dopiero po wojnie, próbując przemyśleć zasadność materializmu historycznego, czego liczne ślady znajdziemy w jego notatnikach. Ważyk, z powołania matematyk, przed wojną nie znał za bardzo ani pism Marksa, ani tym bardziej krytykowanych przez niego ekonomii neoklasycznych, bo czytał głównie odziedziczoną po braciach literaturę piękną i książki historyczne; niespecjalnie znał się też wówczas na filozofii, zwłaszcza społecznej. Po wojnie zachował miłość do matematyki, wyliczeń i statystyk, uprawiając przez przeszło dwadzieścia lat cybernetykę zamiast poetyki, ale tak naprawdę jedyny moment, gdy rzeczywiście stosuje on świadomie kategorie z zakresu ekonomii (w tym wypadku politycznej) to czas powojenny, gdy wychodzą eseje $O$ humanizmie. Widać tam zresztą, że próby rozliczenia romantyzmu podług koncepcji walk klasowych, z zachowaniem rozróżnienia na bazę i nadbudowę, nie są specjalnie udane.

Oprócz refleksji nad filozofią języka awangardowego, kluczowym zadaniem NEC w kwestii naszej historycznej awangardy wydaje się zatem zrekonstruowanie świadomości ekonomicznej epoki oraz wyłaniającego się z niej dyskursu, który dalej nazywać będę „wyobraźnią ekonomiczną" (por. Heinzelmann 1980). Choć wspomniani autorzy o ekonomii piszą dużo, inspirowani marksizmem, Wielkim Kryzysem, a wcześniej szalejącą, powojenną inflacją, rzadziej dokonują autorefleksji nad ekonomią języka literackiego. Zwłaszcza w prozie zdają raczej relację z tego, jak powszechne było projektowanie tematów ekonomicznych na egzystencjalne i jak ta tajemnicza siła, napędzająca stosunki gospodarcze, przeszła na początku XX wieku w tajemnicę samego Życia, zmieniając się w poręczny system metafizyczny. I tak np. w krótkiej nowelce Spirale Stanisława Brucza (w „Almanachu Nowej Sztuki”, w którego kręgu chwilę pozostaniemy) znajdziemy metaforyczny opis nowoczesnego miasta handlowego nad Adriatykiem po I wojnie światowej. O ile w nocy duszą tego miasta jest kino i dancing, a więc mechanicznie reprodukowany rytm nowoczesnego życia, o tyle w dzień jest nim giełda, gwar stosunków handlowych i wymiana towarowa: „Wewnątrz w pasmach błękitno-siwego dymu pływają smagłe, wąsate twarze bałkańskich południowców, wykrzykujących kursy walut: drachmy, franki, dynary... Oto jest czarna giełda — dzienne oblicze duszy powojennego miasta” (Brucz 1924a: 23).

Giełda, jako symbol dynamiki i tajemnicy, chaosu i potencjalności, kryjących się za relacjami handlowymi, była obiektem fascynacji i przekleństwem awangardowej literatury. „Czarna giełda” Brucza to przecież nie realistyczny opis szemranego kantoru, ale — podobnie jak w przypadku kina i dancingu — symbol, którego przemyślenie staje się obowiązkiem awangardowego pisarza. Jak pisał Blaise Cendrars w poemacie Panama (w przekładzie Ważyka, niewątpliwie znanym pozostałym twórcom z kręgu „ANS” i „Zwrotnicy”): „Nie wiem co 
mówią katalogi bibliotek / Nie słucham dzienników finansowych / Mimo że biuletyny giełdy są naszą modlitwą codzienną" (Cendrars 1962: 79). Z kolei Czesław Bobrowski, dokonując wyczerpującego przeglądu prasy francuskojęzycznej, pisze o konstruktywistach z belgijskiego tygodnika „7 arts”: „Dwa słowa powtarzają się najczęściej w «7 arts»: ordre et economie: porządek i ekonomia" (Bobrowski 1925: III). Przywołajmy też uwagi samego Ważyka z eseju napisanego niedługo po wojnie, niewiele różniące się od tych z przedwojennych Mitów rodzinnych:

Stabilizacja oparta na stosunkach gospodarczych z okresu podboju kolonii i surowcowej eksploatacji terenów zamorskich zachwiała się u progu stulecia. [...] Propaganda wzmożonej konsumpcji, zwana w stosunkach handlowych reklamą, zwalczała konserwatywne nawyki mieszczaństwa. Służyły jej wynalazki wielkie i małe, motor spalinowy i cuda toalety. Konsumpcja wyznaczała kierunek zmianom obyczajów. [...] Rozwinęla się turystyka, najdoskonalsza forma konsumpcji. Podróże stały się obowiązkiem i potrzebą nawet drobnej burżuazji. Synowie zawstydzali ojców rozrzutnością, potrzeby ich wzrastały, oszczędności, i tak niepewne, kurczyły się, podnieta i zaspokajanie zmysłów zmieniło się w sens życia. Jakież były jeszcze tajemnice bytu? Konsumpcja wtargnęła do sztuki jako nowa wartość: sycenie zmysłów, upajanie się żywiołem życia. (Ważyk 1949: 33-34)

Zarysowuje tu Ważyk iście dekadencką wizję zmierzchu epoki, która prawem degenerującej się materialnej bazy (hossa nieumiarkowanego potlaczu, zmiana polityki kolonialnej) zaczyna się wyczerpywać, co odbija się w codziennym życiu, w stosunku do przedmiotów i fetyszyzacji doświadczeń. Świadomość społeczna i estetyka pierwszej awangardy rodzą się w specyficznym dla całej europejskiej kultury momencie przesilenia: powolnego odchodzenia burżuazji, której cień naznaczał XIX-wieczne konflikty, przemian kupiectwa, wtargnięcia myśli ekonomicznej na salony. Rynek i napędzająca go reklama okazały się naturalnymi sprzymierzeńcami estetyk awangardowych, ale na krótko. Wciąż brakowało bowiem koncepcji, która pozwoliłaby połączyć w zgodzie z awangardowym zaangażowaniem sztukę, handel i ekonomię polityczną.

Być może jedną z przeszkód była wspomniana już niewiedza samych poetów. Jeden z podstawowych problemów stosowalności analogii ekonomicznej do metaliterackich rozważań w dwudziestoleciu dotyczył bowiem neoklasycznej definicji ekonomii, która zakładała w pewnym uproszczeniu oczywiście - racjonalne gospodarowanie ograniczonymi zasobami. Każdy z elementów tej definicji zawodzi w konfrontacji z samą poezją. Racjonalność zderza się z pragnieniem poluzowania rygorów, uwolnienia wyobraźni, przekraczania granic i rolą przypadku. Podobnie założenie, że język jest ograniczonym zasobem, jest założeniem błędnym, wykluczającym zarówno jego zdolność do historycznej ewolucji, jak i nieskończoną potencjalność generowania nowych znaczeń. Zasady neoklasycznej ekonomii, z jej postulatami racjonalnego oszczędzania i maksymalizacji zysków, nijak miały się więc do poetyckiej praktyki. Typowy dla XIX-wiecznej ekonomii topos homo oeconomicus był przez naszych poetów regularnie krytykowany, najpierw z pozycji lewicowych jako przeżytek burżuazyjny, potem z pozycji psychologiczno-naukowych. Homo futurus miał się stać zaprzeczeniem racjonalnego gospodarza, jego zdolności poznawcze były ograniczone, a jego percepcja chaotyczna i fragmentaryczna, podobnie jak poeinsteinowski świat wokół niego. Im szybciej to odkrywano, tym szybciej zdążano w kierunku utopii, która ów ekonomiczny rachunek zysków i strat czyniła niewiarygodnym i niesprawdzalnym. 
Ekonomiczna analogia Wata, Jasieńskiego czy Sterna nie opierała się oczywiście na refleksji nad miejscem języka w kapitalizmie kognitywnym, lecz czerpała z filozofii pozytywistycznej, socjologii, rosyjskiego formalizmu i początków antropologii, z tematów modnych w epoce i z wczesnych opracowań ekonomicznych na ziemiach polskich. W 1911 roku ukazał się - reklamowany jako pierwszy rodzimy podręcznik do ekonomii — Pieniądz Adama Krzyżanowskiego, a w 1919 roku pomyślana zarazem jako podręcznik, jak i wprowadzenie do zagadnień przemian ekonomicznych i kryzysów związanych z I wojną światową, Nauka o pieniądzu i kredycie tegoż autora. W latach dwudziestych myśl ekonomiczna, zwłaszcza skupiona na problemie kryzysu pieniądza i utrzymania jego wartości, przyrastała wykładniczo i - na skutek kolejnych, nawracających krachów oraz otwartej dyskusji nad finansami państwa - przebijała się do szerokiego obiegu (zwłaszcza liberalna, neoklasyczna szkoła krakowska, por. Lityńska 1983).

Podstawowym problemem naszej gospodarki była po I wojnie światowej kwestia regulacji pieniądza i zapewnienia stabilności waluty w obliczu szalejącej hiperinflacji. Jako że obowiązywał wówczas parytet złota, chodziło przede wszystkim o stworzenie w nowo powstałym państwie rezerw kruszcu, które byłyby zabezpieczeniem emitowanych pieniędzy; udało się tego dokonać, częściowo zresztą, dopiero w 1924 roku po reformach Władysława Grabskiego (doskonałe świadectwo tego chaosu i prób lokowania kapitału w materii znajdziemy w Epizodzie Ważyka). Drugim, długotrwałym problemem okazało się stworzenie stabilnego systemu publicznych finansów opartych w dużej mierze na państwowych kredytach i emisji obligacji. Jeśli przyjrzeć się temu bliżej, ekonomiczna myśl dwudziestolecia w Polsce uruchamiała już analogiczny, charakterystyczny dla całej ekonomii piśmiennej proces odraczania spłaty. Jak prognozował w „Drodze” Ignacy Gliksman, ceniony wówczas ekonomista i specjalista od kwestii ubezpieczeń społecznych: „W braku rezerw pieniężnych rękojmią wykonania zobowiązań przez ubezpieczenia społeczne są siły płatnicze ludności w przyszłości. Jeśli siły te wzrosną, osoby ubezpieczone otrzymają należne im renty” (Gliksman 1936: 16). Rezerwy oczywiście były zbyt skromne i nie mogły pokryć ani ubezpieczeń bieżących, ani rent socjalnych, ani podstawowych zobowiązań państwa w zakresie opieki społecznej. Liczono zatem na wzrastające siły płatnicze w przyszłości, zakładając - w zgodzie z neoklasyczną ekonomią i typowo kapitalistyczną utopią progresywnego rozwoju - ciągły proces bogacenia się ludzkości z kluczowym dla całego modelu zwiększającym się i coraz bardziej odraczanym długiem.

Bardziej znacząca dla analogii ekonomicznej, na której dziś opieramy badania z zakresu ekonomii symbolicznych w literaturze, wydaje się jednak popularność pism Maxa Webera i George’a Simmla. Przypomnijmy, że Filozofia pieniądza ukazała się w Polsce już w roku 1904 w niepełnym tłumaczeniu Leona Belmonta i była znana w kręgach intelektualnych, zwłaszcza niemieckojęzycznych. Simmlem inspirowali się Brzozowski, Leśmian i Irzykowski. Ten ostatni zwracał uwagę na usamodzielnianie się wyższych systemów semiotycznych (nadbudowy) oraz na postępującą alienację: „środki życia pasożytnie przykrywają jego cele i same stają się celami (np. pieniądz)” (Irzykowski 1918: 598). Trudno tego spostrzeżenia nie odnieść do późniejszej, opartej na monetarnej metaforze, antropologii Peipera z Miasta, masy, maszyny...

Ostatni kontekst, który chciałbym przywołać, na ogół pomijany jest w rozważaniach nad popularnością ekonomizacji estetyki w awangardowym dyskursie. Na początku XX wieku rozwijały się na rodzimych uczelniach badania nad filozoficzno-antropologiczną koncepcją, którą dziś uznać byśmy mogli za początki teorii komunikacji i teorii umysłu. Mowa 
oczywiście o propagowanym pod koniec XIX wieku przez Ernsta Macha i Richarda Avenariusa empiriokrytycyzmie, hołdującym zasadzie „ekonomii myślenia”. Obszerną rozprawę na ten temat opublikował choćby Joachim Metallman, przyrodnik i profesor UJ, który przed wojną sformułował holistyczną koncepcję kultury opartą na emergencji, a więc niewyprowadzalności systemu z jego elementów składowych. Położył on fundament pod naukowy konstruktywizm oraz teorię systemów w obrębie cybernetyki. Zanim jednak do tego doszło, przedstawiał naukowe zastosowania omawianej metody, która była tyleż wykładem metodologii nowoczesnej nauki, co filozofią duszy:

zestawiając rezultat analizy teorio-poznawczej pewnego pojęcia z jego codziennym, zdawkowym znaczeniem, z jego prostą funkcją, usiłując pogodzić stanowisko naiwne, które „daje” nam substancje, rzeczy, siły z rezultatem krytyki, która zamienia „byty” na złożone pojęcia ukryte w niezmiennie prostych wyrazach, stajemy przed objawem ekonomii. (Metallman 1914: 11)

Dodajmy, że z naszego kręgu zainteresowań, tzn. pierwszej awangardy, z Metallmanem współpracował choćby Leon Chwistek, który od sztuki formistycznej, działającej w zgodzie z ekonomią myślenia, przeszedł w latach trzydziestych do teorii mnogich rzeczywistości i estetyki antyunistycznej. Przyszły wybitny antropolog, Bronisław Malinowski, ekonomii myślenia poświęcił obroniony na UJ doktorat - O zasadzie ekonomii myślenia (1980). Zagadnienie to pozostawało istotne nie tylko dla Witkacego czy Chwistka, ale też np. dla Ważyka, za sprawą czytanego przez niego uważnie matematyka (a potem filozofa) Henriego Poincarégo.

$\mathrm{Na}$ bazie szkiców polskich epistemologów z tamtych czasów możemy prześledzić, jak „ekonomia myślenia” usamodzielnia się i przenosi na różne systemy semiotyczne, oznaczając w zależności od kontekstu: zwięzłość, klarowność, kondensację, oszczędność, krytycyzm lub pragmatyzm. Za wszystkimi tymi wystąpieniami słowa w kontekście teorii informacji a więc ekonomicznego formułowania myśli i posługiwania się językiem — stoi przesłanka o minimalizacji kosztów (energetycznych) i maksymalizacji korzyści poznawczych (ustalanie twierdzeń fundamentalnych i klarownych tez). Z jednej strony jest to zakorzenione w filozofii języka, nic więc dziwnego, że wpłynęło na brytyjską filozofię nauki. Z drugiej zaś do całej koncepcji prowadziły rozważania kontynentalne, zmierzające do opisania nowoczesnej fenomenologii percepcji (Husserl). Nie powinno więc dziwić, że zarówno grupa "Zwrotnicy”, jak i nieco późniejsza grupa „Almanachu Nowej Sztuki” kwestię percepcji połączyły bezpośrednio z poetyką oraz zdolnością wiersza do nazywania rzeczywistości. Różnice między Peiperem (jako teoretykiem tej pierwszej) i np. Gackim czy Ważykiem (związanymi z tą drugą) są oczywiście zasadnicze, ale nie aż takie, żeby znaczenie „ekonomii myślenia” w oszczędnej budowie zdania Nowej Sztuki mogło zostać przeoczone. Dopiero wyczerpująca rekonstrukcja składowych mód intelektualnych, użyć i inspiracji, pozwoli nam bowiem z większym zrozumieniem spojrzeć na historyczny potencjał ekonomicznych analogii w manifestach i wierszach Peipera, Sterna, Kurka czy Wata, a tym samym odnieść je do aktualnych debat i metaliterackich głosów twórców, którzy wprost nawiązują do poetyk dwudziestowiecznej awangardy. 


\section{Bibliografia}

Awangarda jest rewolucyjna albo nie ma jej wcale (2019), red. Sosnowski A., Orska J., WBPiCAK, Poznań.

Baron-Milian Marta (2015), Wat plus Vat. Zwiazki literatury i ekonomii w twórczości. Aleksandra Wata, Wydawnictwo UŚ, Katowice.

Berardi Franco (2012), The Uprising: On Poetry and Finance, Semiotext(e), Los Angeles, Calif. Bobrowski Czesław (1925), Czasopisma francuskie, „Almanach Nowej Sztuki”, nr 2 (4).

Brucz Stanisław (1924a), Spirale (fragment noweli), „Almanach Nowej Sztuki”, nr 1 (1). - (1924b), Zarys nowej poetyki, „Almanach Nowej Sztuki”, nr 2 (2).

Bürger Peter (2006), Teoria awangardy, przeł. J. Kita-Huber, red. nauk. Wilkoszewska K., Universitas, Kraków.

Cendrars Blaise (1962), Poezje, red. Ważyk A., PIW, Warszawa.

Cocteau Jean (1922), Le Secret professionnel, Libraire Stock, Paris.

- (1925), Sekrety zawodowe (wybór fragmentów), przeł. A. Wat, „Almanach Nowej Sztuki”, nr 2 (4).

Ekonomia literatury: antologia (2017), red. Ratajczak M., Tomczok P., Wydawnictwo UŚ, Katowice.

Gacki Stefan Kordian (1924), Sztuka ludzka, „Almanach Nowej Sztuki”, nr 1.

- (1925a), Punkt wejścia nowej sztuki, „Reflektor”, nr 2.

- (1925b), Na drodze do nowego klasycyzmu, „Almanach Nowej Sztuki”, nr 1(3).

Gliksman Ignacy (1936), Drogi i manowce systemu ubezpieczeń w Polsce, „Droga”, nr 1.

Goux Jean-Joseph (1990), Symbolic Economies: After Marx and Freud, Cornell UP, Ithaca, N.Y. Graeber David (2001), Toward an Anthropological Theory of Value: The False Coin of Our Own Dreams, Palgrave, New York.

Heinzelmann Kurt (1980), The Economics of the Imagination, University of Massachusetts Press, Amherst.

Hörisch Jochen (2010), Orzet czy reszka. Poezja pieniądza, przeł. J. Kita-Huber, S. Huber, Universitas, Kraków.

Irzykowski Karol (1918), Simmel, „Maski”, z. 30.

Jakobson Roman (1989), Co to jest poezja?, przeł. M.R. Meyenowa [w:] tegoż, W poszukiwaniu istoty jezyka, red. Mayenowa M.R., t. 2, Warszawa.

Jasieński Bruno (1972), Utwory poetyckie. Manifesty. Szkice, oprac. E. Balcerzan, Zakład Narodowy im. Ossolińskich, Wrocław - Warszawa - Kraków - Gdańsk.

Kłosiński Michał (2015), Ekonomia i polityka w polskiej poezji lat dwudziestych [w:] Papież awangardy. Tadeusz Peiper w Hiszpanii, Polsce, Europie, red. Rypson P., Muzeum Narodowe w Warszawie, Warszawa.

- (2017), Wojownicy awangardy - projekty ekonomiczno-spoteczne w manifestach literackich Brunona Jasieńskiego [w:] Ekonomie w literaturze i kulturze, red. Cymbrowski B., Tomczok P., Wydawnictwo Uniwersytetu Śląskiego, Katowice.

Kurek Jalu (1932), Elementy: linia prosta, „Linia”, nr 4.

Lazzarato Maurizio (2014), Signs and Machines: Capitalism and the Production of Subjectivity, trans. J.D. Jordan, Semiotext(e), Los Angeles, CA.

Linde Samuel Bogumił (1807), Stownik jezzyka polskiego, Tom I, część I, Drukarnia XX. Piiarów, Warszawa. 
Literackie ekonomie (2017), red. Wolski P., Tomczok P., Wydawnictwo UŚ, Warszawa-Katowice. Lityńska Aleksandra (1983), Szkota Krakowska (1921-1939), AE, Kraków.

Łapiński Zdzisław (2002), „Psychosomatyczne sq te moje wiersze” (Impuls motoryczny w poezji Juliana Przybosia), „Teksty Drugie”, nr 6.

Łobodowski Józef (1934/35), Pisarz rewolucyjny w teraźniejszości, „Dźwigary”, nr 2.

Malinowski Bronisław (1980), Dzieta. T. 1. Wierzenia pierwotne i formy ustroju spotecznego. $O$ zasadzie ekonomii myślenia : pogląd na geneze religii ze szczególnym uwzględnieniem totemizmu, oprac. A.K. Pauch, PWN, Warszawa.

Marazzi Christian (2008), Capital and Language. Form the New Economy to the War Economy, introduction by M. Hardt, trans. G. Conti, Semiotexte(e), Los Angeles, Calif.

Markowski Michał Paweł (2004), Reprezentacja i ekonomia, „Teksty Drugie”, nr 4.

Marks Karol (1951), Kapitat. Krytyka ekonomii politycznej - Tom I - Ksiega I - Proces wytwarzania kapitatu, Książka i Wiedza, Warszawa.

Metallman Joachim (1914), Zasada ekonomii myślenia, jej historya i krytyka, Drukarnia W.L. Anczyca i Spółki, Warszawa.

Nycz Ryszard (1997), Jezyk modernizmu. Prolegomena historycznoliterackie, Wydawnictwo „Leopoldinum” Fundacji dla Uniwersytetu Wrocławskiego, Wrocław.

Peiper Tadeusz (1923), Sprawa jezykowa, „Zwrotnica”, nr 4.

- (1979), Pisma wybrane, oprac. S. Jaworski, Zakład Narodowy im. Ossolińskich, WrocławWarszawa-Kraków-Gdańsk.

Poggioli Renato (1981), The Theory of the Avant-garde, trans. G. Fitzgerald, Cambridge, Massachusetts.

Przyboś Julian (1926), Cztowiek w rzeczach, „Zwrotnica”, nr 7.

Romantyczny antykapitalizm (2018), red. Pospiszyl M., Czeczot K., IBL PAN, Warszawa.

Sieburth Richard (1987), In Pound We Trust: The Economy of Poetry/The Poetry of Economics, "Critical Inquiry”, Vol. 14, No. 1.

Stern Anatol (1972), O poetach Nowej Sztuki (list do redaktora Almanachu) [w:] tegoż, Gtód jednoznaczności i inne szkice, Czytelnik, Warszawa.

Świeściak Alina (2015), Fikcja awangardy?, „Teksty Drugie”, nr 6.

The New Economic Criticism. Studies at the Intersection of Literature and Economics (2005), ed. Woodmansee M., Osteen M., Routlegde, London-New York.

Tomczok Paweł (2017), Abstrakcje i klasy. Marksizm, ekonomia, literatura [w:] Ekonomiczne teorie literatury, red. Kłosiński M., Tomczok P., Wydawnictwo UŚ, Katowice.

- (2018), Literacki kapitalizm. Obrazy abstrakcji ekonomicznych w literaturze polskiej drugiej potowy XIX wieku, Wydawnictwo UŚ, Katowice.

Turowski Andrzej (1990), Wielka utopia awangardy: artystyczne i spoteczne utopie w sztuce rosyjskiej 1910-1930, PWN, Warszawa.

Ważyk Adam (1949), Źródta wspótczesnej poezji we Francji [w:] tegoż, W stronę humanizmu, Czytelnik, Warszawa.

- (1982), Eseje literackie, Czytelnik, Warszawa.

- (1983), Amfion. Rozważania nad wierszem polskim, Czytelnik, Warszawa. 